DOI: https://doi.org/10.24127/ajpm.v10i4.3887

\title{
BAGAIMANA BENTUK TUGAS MATEMATIKA YANG MAMPU MENDORONG MUNCULNYA PENALARAN IMITATIF DAN KREATIF?
}

\author{
Kusaeri $^{1^{*}}$, Yuni Arrifadah ${ }^{2}$, Anni Mujahidad Dina ${ }^{3}$ \\ ${ }^{1,2,3}$ UIN Sunan Ampel, Surabaya, Indonesia \\ *Corresponding author. \\ E-mail: $\quad \underline{\text { kusaeri@uinsby.ac.id }}^{\left.{ }^{*}\right)}$ \\ yuni.arrifadah@uinsby.ac.id ${ }^{2)}$ \\ annimujahidaddina@gmail.com ${ }^{3)}$
}

Received 30 June 2021; Received in revised form 13 September 2021; Accepted 15 December 2021

\begin{abstract}
Abstrak
Tugas matematika di Indonesia didominasi oleh jenis closed task. Padahal untuk mempelajari penalaran imitatif dan kreatif, siswa harus berlatih berbagai macam jenis tugas di antaranya closed task dan open task. Penelitian ini bertujuan untuk: mendeskripsikan desain closed task dan open task yang mampu mendorong munculnya penalaran imitatif dan kreatif. Penelitian ini merupakan penelitian deskriptif kualitatif. Subjek dalam penelitian ini adalah siswa SMPN 4 Waru yang dipilih menggunakan teknik purposive sampling. Data dikumpulkan melalui teknik catatan lapangan, tes penalaran imitatif dan kreatif, serta wawancara berbasis tugas. Data dianalisis dengan cara membandingkan tabulasi terkait ketercapaian indikator tipe penalaran imitatif (MR dan AR) serta indikator tipe penalaran kreatif (LCR dan GCR) pada masing-masing tugas berdasarkan hasil wawancara dan hasil tes penalaran imitatif dan kreatif. Hasil penelitian menunjukkan bahwa closed task yang menanyakan rumus suku ke- $n$ yang telah diketahui siswa akan memunculkan tipe MR, sebaliknya closed task yang berkaitan dengan penerapan rumus yang telah diketahui siswa untuk mencari suku selanjutnya dari suatu barisan bilangan akan memunculkan tipe AR. Open task yang menanyakan pola ke- $n$ dari konfigurasi objek dan banyak melibatkan hal baru bagi siswa akan cenderung memunculkan tipe GCR, sebaliknya open task yang menanyakan suku selanjutya dari barisan bilangan dan tidak sepenuhnya baru/banyak melibatkan hal-hal yang telah diketahui siswa cenderung memunculkan tipe LCR.
\end{abstract}

Kata kunci: Closed Task; Open Task; Penalaran Imitatif; Penalaran Kreatif.

\begin{abstract}
Mathematical tasks in Indonesia are dominated by closed task type. However to learn imitative and creative reasoning that plays an important role in producing conclusions when completing assignments, students must practice various types of tasks including closed tasks and open tasks. Therefore, this study aims to: 1) describe the closed task and open task designs that encourage the emergence of imitative and creative reasoning, 2) describe the relationship between closed tasks and open tasks given with the emerging types of imitative and creative reasoning. This research is a design research and the subjects were 5 students of SMPN 4 Waru who selected by using purposive sampling technique. The data collection techniques used field notes, imitative and creative reasoning tests, and task-based interviews. In general, designing closed tasks and open tasks that encourage imitative and creative reasoning is carried out based on the stages of theories from Gravemeijer and Cobb. Start with compiling the HLT, designing assignments according to: 1) the 2013 curriculum, 2) the materials and assignments that students have encountered and never encountered, doing experiment, then the data obtained were analyzed using HLT theory. Giving closed tasks that asks for a formula that students known tends to bring up the MR type, while those related to the application of the formula tend to bring up the AR type. Giving open tasks that can be interpreted in a variety of ways and involves a lot of new things for students tends to bring up the GCR type, if it involves a lot of things that students already know it tends to bring up the LCR type.
\end{abstract}

Keywords:Closed Task; Creative Reasoning; Imitative Reasoning; Open Task.

This is an open access article under the Creative Commons Attribution 4.0 International License 
DOI: https://doi.org/10.24127/ajpm.v10i4.3887

\section{PENDAHULUAN}

Penalaran merupakan salah satu kemampuan matematika yang sangat penting dalam pembelajaran. Sebab penalaran menjadi kemampuan dasar yang diperlukan dalam mengembangkan kemampuan matematika (Sukirwan et al., 2018), terutama dalam memecahkan masalah matematika (Sutini et al., 2020). Dengan kata lain, penalaran menjadi kemampuan matematika dasar yang harus dimiliki semua siswa.

Terdapat dua jenis penalaran yang sering digunakan siswa dalam menyelesaikan tugas-tugas matematika yaitu penalaran imitatif dan penalaran kreatif (Boesen et al., 2010). Penalaran imitatif merupakan kemampuan membangun tiruan jawaban maupun algoritme melalui proses mengingat kembali. Sementara penalaran kreatif diartikan sebagai kemampuan dalam memunculkan unsur novelty, flexibility, mathematical foundation, dan plausibility berdasarkan bekal pengetahauan yang telah dimiliki.

Penalaran imitatif dibagi lagi ke dalam dua tipe yaitu Memorized Reasoning (MR) dan Algorithmic Reasoning (AR) (Lithner, 2015). MR merupakan sebuah penalaran yang pemilihan strateginya dibangun dengan cara mengingat kembali jawaban secara lengkap dan implementasi strateginya hanya menuliskannya secara berulang (Palm et al., 2011). Sementara itu, AR merupakan penalaran yang pemilihan strateginya didapatkan melalui pemanggilan kembali algoritma dan implementasi strateginya adalah dengan mengaplikasikan algoritma yang telah dipilih (Lithner, 2015).

Di sisi lain, penalaran kreatif juga dikelompokkan ke dalam dua tipe: (1) Local Creative Reasoning (LCR) yaitu penalaran yang menggunakan algoritma umum yang sudah diketahui oleh banyak orang pada semua langkah penyelesaian, kecuali suatu langkah tertentu yang tidak lazim atau non rutin, dan (2) Global Creative Reasoning (GCR) yaitu penalaran yang digunakan untuk menyelesaikan suatu masalah matematika yang memerlukan penalaran kreatif pada keseluruhan tahapan penyelesaian masalah matematika yang dilakukan (Bergqvist, 2012).

Sejumlah studi mengungkapkan bahwa kondisi penalaran matematis siswa jenjang Sekolah Menengah Pertama (SMP) di Indonesia tergolong rendah (Ayal et al., 2016; Rosita et al., 2020; Sukirwan et al., 2018). Penelitian lain menunjukkan bahwa dari 27 siswa, hanya terdapat $29,63 \%$ siswa yang memiliki penalaran kategori baik dan sangat baik, sedangkan 70,37\% sisanya siswa dengan kategori "sedang" hingga "sangat rendah" (Rizta et al., 2013). Pada Ujian Nasional (UN) 2018, ketika mereka dihadapkan pada soal matematika yang menuntut strategi baru dalam proses penyelesaiannya (mirip soal yang diujikan dalam PISA), hanya sebagian kecil (18\%) siswa yang dapat menjawab soal ini dengan benar. Sebaliknya, lebih dari $73 \%$ mampu menyelesaikan dengan baik soal-soal yang jawabannya dapat diperoleh secara langsung dengan menerapkan rumus/ prosedur matematika (Kusaeri, 2020).

Berdasarkan uraian di atas, maka diperlukan perhatian lebih terhadap cara pemberian tugas yang dimaksudkan guna meningkatkan kemampuan matematika siswa, utamanya dalam mengembangkan penalaran matematis (Johnson, Coles, \& Clarke, 2017; Olsson, 2019). Hal itu dipertegas penelitian yang dilakukan Sidenvall et al., (2015) menemukan bahwa tugas matematika memberikan andil yang siginifikan terhadap kemampuan penalaran siswa. 
DOI: https://doi.org/10.24127/ajpm.v10i4.3887

Penelitian dalam kaitanya dengan penalaran matematis dikaitkan dengan tugas telah mendapatkan perhatian banyak peneliti. Misalnya penelitian yang dilakukan oleh Jones \& Pepin (2016); Koichu, Zaslavsky \& Dolev (2016) dan Swan (2011) fokus dalam merancang tugas matematika yang mampu menantang siswa. Selanjutnya, penelitian yang mengungkap prinsip mendesain tugas yang dapat memunculkan penalaran imitatif dan kreatif dilakukan oleh Lithner (2017). Penelitian Boesen et al. (2010) berupaya mengungkap hubungan antara tipe tugas dengan penalaran matematis yang digunakan siswa. Namun, penelitian ini hanya terbatas pada penalaran imitatif tipe MR dan AR serta penalaran kreatif secara umum.

Sejumlah penelitian yang terungkap, belum satupun yang fokus mengangkat variasi jenis tugas. Padahal, variasi jenis tugas menurut Bergqvist \& Lithner (2012) sangat diperlukan karena untuk mempelajari berbagai jenis penalaran matematis siswa harus berlatih berbagai jenis tugas, dan penalaran imitatif maupun kreatif sangat penting bagi siswa guna menyelesaikan tugas yang karakteristiknya sesuai. Bagaimanapun, jenis tugas yang berbeda memiliki peran, bobot, serta potensi yang berbeda dalam pembelajaran matematika (Berisha \& Bytyqi, 2020). Artinya, suatu jenis tugas memberikan pengalaman tersendiri yang mungkin saja tidak didapatkan dari jenis tugas lain.

Hasil-hasil penelitian yang telah dibahas tersebut mengindikasikan perlunya merancang variasi jenis tugas matematika, baik bentuk closed task dan open task yang mampu mendorong munculnya penalaran imitatif dan kreatif siswa. Itulah gap yang akan diisi melalui penelitian ini. Oleh karena itu, penelitian ini bertujuan untuk mendeskripsikan bentuk closed task dan open task yang mampu mendorong munculnya penalaran imitatif dan kreatif.

\section{METODE PENELITIAN}

Pendekatan yang digunakan dalam penelitian ini adalah kualitatif. Alasan pemilihan pendekatan ini adalah untuk mengenali dan mengungkap karakteristik tugas dalam tipe penalaran imitatif dan kreatif.

Penelitian dilakukan di SMP Negeri 4 Waru, melibatkan 48 siswa (32 siswa kelas unggulan dan 16 siswa kelas reguler). Dari 48 subjek keseluruhan, didapatkan kesamaan pada beberapa hasil penyelesaian sebagai dampak dari pelaksanaan uji coba secara daring. Pada akhirnya dilakukan pengerucutan menjadi 5 subjek terpilih menggunakan teknik purposive sampling. Pemilihan ini dilakukan dengan mempertimbangkan perbedaan hasil penyelesaian serta tipe penalaraan imitatif dan kreatif yang dimunculkan selama proses penyelesaian tugas.

Instrumen dalam penelitian ini berupa lembar tes penalaran imitatif dan kreatif serta pedoman wawancara. Lembar tes penalaran imitatif dan kreatif terdiri dari 2 closed task dan 2 open task, masing-masing diadaptasi dari buku siswa terbitan Kemendikbud RI yang ditulis oleh As'ari et.al dan disesuaikan dengan karakteristik closed task dan open task pada Tabel Pertanyaan pada pedoman wawancara dibangun berdasarkan unsur penalaran imitatif yaitu plausibility, mathematical foundation, dan imitation (Permatasari et al., 2020) dan unsur penalaran kreatif yaitu mathematical foundatiom, plausibility, novelty, flexibility Bergqvist, 2007). 
DOI: https://doi.org/10.24127/ajpm.v10i4.3887

Tabel 1. Karakteristik Closed Task dan Open Task

\begin{tabular}{|c|c|}
\hline Closed Task & Open Task \\
\hline $\begin{array}{l}\text { Hanya } \\
\text { memungkinkan } \\
\text { aplikasi } 1 \text { strategi } \\
\text { penyelesaian }\end{array}$ & $\begin{array}{l}\text { Memungkinkan } \\
\text { untuk } \\
\text { diaplikasikan } \\
\text { sejumlah strategi } \\
\text { penyelesaian }\end{array}$ \\
\hline $\begin{array}{l}\text { Memiliki } \\
\text { ketunggalan } \\
\text { jawaban benar }\end{array}$ & $\begin{array}{l}\text { Jawaban benar } \\
\text { dapat lebih dari } \\
\text { satu }\end{array}$ \\
\hline $\begin{array}{l}\text { Menciptakan } \\
\text { kemudahan } \\
\text { peyelesaian bagi } \\
\text { siswa }\end{array}$ & $\begin{array}{l}\text { Memunculkan } \\
\text { tantangan bagi } \\
\text { siswa }\end{array}$ \\
\hline
\end{tabular}

Pengumpulan data penelitian menggunakam teknik tes penalaran imitatif dan kreatif serta wawancara. Dalam pelaksanaanya, pengumpulan data dilangsungkan secara daring mengingat anjuran pemerintah untuk melaksanakan social distancing. Sehingga pemberian tes melalui google classrom dan pelaksanaan wawancara melalui bantuan aplikasi zoom, menjadi opsi tepat di masa pandemi ini. Oleh karena itu, proses pengerjaan tes penalaran imitatif dan kreatif dilakukan dalam waktu dua jam. Pemberian batas waktu sangat diperlukan untuk meminimalisir ketidakjujuran dalam penyelesaian.

Data yang diperoleh dianalisis dengan cara membandingkan melalui pembuatan tabulasi terkait ketercapaian indikator tipe penalaran imitatif (MR dan AR) serta indikator tipe penalaran kreatif (LCR dan GCR) pada masingmasing jenis tugas. Data hasil wawancara dianalisis melalui tiga tahapan yaitu reduksi data, penyajian data, dan penarikan kesimpulan. Penggabungan data hasil tes penalaran imitatif dan kreatif dengan data hasil wawancara dimaksudkan untuk menguji validitas data melalui teknik triangulasi sumber data. Penelitian ini juga memanfaatkan teknik trackability atau observasi jalur proses pembelajaran untuk menggambarkan informasi yang didapatkan secara mendetail tanpa adanya kesalahan (Prahmana, 2016).

\section{HASIL DAN PEMBAHASAN}

Tugas dalam penelitian ini didefinsikan sebagai masalah atau pertanyaan tunggal yang melibatkan siswa pada ide matematika. Terdapat 4 tugas yang digunakan dan dikelompokkan berdasarkan jenis dan topik yang termuat dalam tugas. Karakteristik masing-masing tugas disajikan pada Tabel 2.

Tabel 2. Karakteristik Tugas pada Setiap Nomor

\begin{tabular}{ccl}
\hline $\begin{array}{c}\text { Tugas } \\
\text { Ke- }\end{array}$ & $\begin{array}{c}\text { Jenis } \\
\text { Tugas }\end{array}$ & \multicolumn{2}{c}{ Topik Tugas } \\
\hline 1 & $\begin{array}{c}\text { Closed } \\
\text { task }\end{array}$ & $\begin{array}{l}\text { Mencari suku ke-n } \\
\text { dari cerita yang } \\
\text { disajikan }\end{array}$ \\
\hline 2 & $\begin{array}{c}\text { Closed } \\
\text { task }\end{array}$ & $\begin{array}{l}\text { Mencari rumus } \\
\text { suku ke- } n \text { dari } \\
\text { konfigurasi objek } \\
\text { yang disajikan }\end{array}$ \\
\hline 3 & Open task & $\begin{array}{l}\text { Mencari suku ke-n } \\
\text { dari cerita yang } \\
\text { disajikan }\end{array}$ \\
\hline 4 & Open task & $\begin{array}{l}\text { Mencari rumus } \\
\text { suku ke- } n \text { dari } \\
\text { konfigurasi objek } \\
\text { yang disajikan }\end{array}$ \\
& & \multicolumn{2}{c}{} \\
& &
\end{tabular}

Penalaran imitatif yang muncul pada penyelesaian masing-masing tugas, diukur sesuai dengan indikator tipe penalaran imitatif di Tabel 3 . Sementara penalaran kreatif yang muncul, diukur berdasarkan indikator tipe penalaran kreatif pada Tabel 4 . 
DOI: https://doi.org/10.24127/ajpm.v10i4.3887

Tabel 3. Indikator Tipe Penalaran Imitatif

\begin{tabular}{|c|c|c|}
\hline \multirow{2}{*}{$\begin{array}{c}\text { Unsur } \\
\text { Penalaran } \\
\text { Imitatif }\end{array}$} & \multicolumn{2}{|c|}{ Indikator } \\
\hline & MR & $\mathbf{A R}$ \\
\hline $\begin{array}{l}\text { Mathematical } \\
\text { foundation }\end{array}$ & 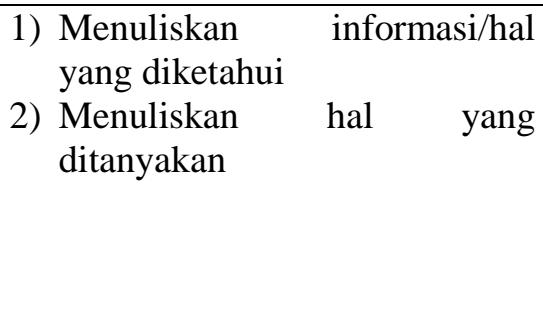 & $\begin{array}{l}\text { 1) Menuliskan informasi/hal yang } \\
\text { diketahui } \\
\text { 2) Menuliskan hal yang } \\
\text { ditanyakan } \\
\text { 3) Melakukan perhitungan atau } \\
\text { tindakan melalui algoritma } \\
\text { yang dipilih }\end{array}$ \\
\hline Imitation & $\begin{array}{l}\text { Menuliskan jawaban yang } \\
\text { didapatkan dari hasil mengingat } \\
\text { kembali jawaban secara lengkap. }\end{array}$ & $\begin{array}{l}\text { Menuliskan algoritma yang } \\
\text { didapatkan dari hasil mengingat } \\
\text { kembali algoritma yang telah } \\
\text { didapatkan sebelumnya. }\end{array}$ \\
\hline Plausibility & $\begin{array}{lcr}\text { Memberikan } & \text { alasan } & \text { atau } \\
\text { argumentasi } & \text { logis } & \text { terkait } \\
\text { pemilihan jawaban } & \end{array}$ & $\begin{array}{lcr}\text { Memberikan } & \text { alasan } & \text { atau } \\
\text { argumentasi } & \text { logis } & \text { terkait } \\
\text { pemilihan algoritma } & \end{array}$ \\
\hline
\end{tabular}

Tabel 4. Indikator Tipe Penalaran Kreatif

\begin{tabular}{|c|c|}
\hline \multirow{2}{*}{$\begin{array}{c}\text { Unsur Penalaran } \\
\text { Kreatif }\end{array}$} & Indikator \\
\hline & GCR \\
\hline $\begin{array}{l}\text { Mathematical } \\
\text { foundation }\end{array}$ & $\begin{array}{l}\text { 1) Menyebutkan hal-hal yang diketahui pada tugas. } \\
\text { 2) Menyebutkan hal harus diselesaikan pada tugas. } \\
\text { 3) Menentukan strategi yang didasarkan pada sifat instrinsik } \\
\text { matematika dan relevan dengan hal yang diketahui pada tugas. } \\
\text { 4) Menerapkan strategi yang yang telah dipilih. }\end{array}$ \\
\hline Novelty & $\begin{array}{lllr}\text { 1) } \begin{array}{l}\text { Mengembangkan satu unsur } \\
\text { kebaruan dalam rangkaian }\end{array} & \begin{array}{l}\text { Mengembangkan } \\
\text { kebaruan dalam }\end{array} & \begin{array}{r}\text { unsur } \\
\text { seluruh } \\
\text { rangkaian }\end{array} \\
\text { penyelesaian tugas. } & \text { stragi } \\
\text { 2) } \begin{array}{lll}\text { Menerapkan strategi yang } \\
\text { telah dikembangkan untuk }\end{array} & \text { 2) } \begin{array}{l}\text { Menerapkan strategi yang } \\
\text { telah dikembangkan untuk } \\
\text { menyelesaikan tugas. }\end{array} & \begin{array}{l}\text { menyelesaikan tugas. } \\
\end{array} & \end{array}$ \\
\hline Flexibility & Menggunakan minimal 2 cara penyelesaian yang berbeda \\
\hline Plausibility & $\begin{array}{l}\text { 1) Menjelaskan hubungan dari hal-hal yang diketahui. } \\
\text { 2) Menjelaskan kesesuaian antara hal yang diketahui dengan hal yang } \\
\text { ditanyakan. } \\
\text { 3) Memberikan alasan logis terkait strategi penyelesaian tugas } \\
\text { dikembangkan. } \\
\text { 4) Menyampaikan alasan logis mengenai penerapan strategi yang } \\
\text { dikembangkan. } \\
\text { 5) Menjelaskan kesesuaian hadil yang didapatkan dengan pertanyaan } \\
\text { tugas. }\end{array}$ \\
\hline
\end{tabular}


DOI: https://doi.org/10.24127/ajpm.v10i4.3887

Dari Tabel 3 dan Tabel 4 diketahui bahwa banyaknya indikataor pada setiap unsur tidaklah sama. Hal yang menarik adalah terdapat kesamaan pada seluruh indikator unsur mathematical foundation, flexibility, dan plausibility antara tipe LCR dan GCR. Satu-satunya indikator berbeda terletak pada unsur novelty. Sebab, pembagian ke dalam tipe LCR dan GCR dilakukan berdasarkan sedikit banyaknya algoritma maupun penalaran kreatif yang digunakan (An et al., 2017).

Pada tugas ke-1, terdapat 5 penyelesaian yang berhasil dikumpulkan. Siswa tidak merasa kesulitan menyebutkan informasi dan hal yang ditanyakan pada tugas secara lengkap. Sebab perumusan tugas serta penyajian data yang diperlukan untuk menyelesaikan tugas secara jelas, menjadi salah satu karakteristik closed task (Romli, 2019). Hanya terdapat satu penyelesaian pada Gambar 1 yang tidak melibatkan kalkulasi, artinya penyelesaian tersebut tidak memenuhi salah satu indikator mathematical foundation pada penalaran imitatif tipe AR. Proses ini terlewatkan sebab hal yang diingat siswa bukanlah rumus dari barisan bilangan Fibonacci, melainkan anggotanya. Pada dasarnya, penalaran imitatif berkaitan erat dengan proses mengingat kembali (Bergqvist \& Lithner, 2012). Oleh karena itu, daya ingat siswa berperan penting dalam menentukan tipe penalaran imitatif yang dimunculkan. Ketika menghadapi closed task yang berkaitan dengan penentuan suku selanjutnya, siswa cenderung mengingat algoritme dari suatu barisan bilangan dibanding mengingat anggota dari suatu barisan bilangan.
Sebagian besar siswa mengidentifikasi jenis pola bilangan dalam cerita, kemudian menuliskan rumus $U_{n}$ dari barisan bilangan Fibonacci seperti yang tersaji pada Gambar 2. Hal yang menarik adalah penjelasan terkait penyalinan algoritme yang tepat disampaikan tanpa adanya keraguan seakan-akan sudah sangat familier dengan rumus tersebut. Sebaliknya, siswa yang tidak dapat menuliskan dan menjelaskan rumus/algoritme yang digunakan meskipun telah melakukan kalkulasi tertentu, terkesan ragu-ragu terhadap apa yang dilakukan sebagaimana pernyataannya: "Saya tidak tahu, tapi seperti pernah dengar".

Kegiatan imitasi algoritme maupun jawaban tugas yang dilakukan oleh siswa menunjukkan bahwa tidak terdapat hal baru dalam penyelesaian pada tugas ke-1. Lithner (2017) menyebutkan bahwa apabila suatu penyelesaian tugas telah diberikan sebelumnya, maka siswa cenderung menggunakannya tanpa ada keinginan untuk mengeksplor lebih lanjut. Dengan kata lain, penyelesaian tugas ke-1 tidak memunculkan unsur novelty penalaran tipe LCR maupun GCR.

Argumentasi yang disampaikan untuk mendukung penyelesaian yang melibatkan penyalinan jawaban, berdasar pada daya ingat dengan beralasan pernah menemui tugas yang sejenis. Sementara pada penyelesaian yang melibatkan penyalinan algoritme, argumentasi yang disampaikan mempertimbangkan sifat intrinsik matematika yaitu dengan mengidentifikasi barisan bilangan pada cerita yang disajikan. Kedua jenis argumentasi yang disampaikan dapat diterima, karena dalam penalaran imitatif siswa tidak perlu mempertimbangkan sifat intrinsik matematika (Boesen et al., 2010). 
DOI: https://doi.org/10.24127/ajpm.v10i4.3887

Argumentasi dalam penalaran imitatif menjadi tidak logis ketika pernyataan yang disampaikan saling bertolak belakang. Sebagai contoh, seorang siswa pada awalnya memberi pernyataan berikut: "Maksud dari +1 adalah bertambahnya uang". Kemudian pada pertanyaan berikutnya dia menyatakan : "Ditambahkan 1 karena dari ceritanya Budi memasukkan masing-masing 1 koin pada hari kedua dan ketiga”.

Sebaliknya siswa yang menyampaikan argumentasi berdasarkan daya ingat dan pengalaman, tidak dapat disebut memunculkan penalaran kreatif. Sebab, unsur plausibility pada penalaran kreatif menyebutkan bahwa siswa harus memberikan argumentasi yang logis, benar, dan masuk akal (Dwirahayu et al., 2021).

Pada tugas ke-2, terdapat 5 penyelesaian yang berhasil dikumpulkan. Seluruh penyelesaian berhasil menyebutkan informasi dan pertanyaan tugas dengan lengkap. Akan tetapi, hanya penyelesaian pada Gambar 3 yang dapat menuliskan kalkulasi tertentu untuk mendapatkan rumus suku ke- $n$ dari konfigurasi objek yang disajikan.

Kondisi ini dikarenakan, hal yang disalin siswa pada penyelesaian tersebut merupakan rumus/algoritme aritmatika bertingkat yang dia dapatkan selama pembelajaran daring. Meskipun demikian, sebagian besar siswa justru cenderung menyalin jawaban dari tugas atau materi yang pernah ditemui ketika menghadapi closed task yang berkaitan dengan penentuan rumus suku ke- $n$ dari konfigurasi objek yang disajikan. Perbedaan ini tidak menjadi suatu masalah yang menghambat penyelesaian tugas, asalkan penyalinan algoritme dilakukan dengan tepat. Sebab, hal dasar dari AR adalah bagaimana menentukan algoritme yang sesuai dan sisanya merupakan penerapan algoritme (Palm et al., 2011). Adanya proses penyalinan menunjukkan bahwa kelima penyelesaian berhasil memunculkan unsur imitation pada penalaran imitatif. Sebaliknya, tidak berhasil memunculkan unsur novelty pada penalaran kreatif. Sementara argumentasi yang diberikan siswa untuk mendukung penyalinan jawaban cukup beragam, mulai dari mengingat rumus suku ke- $n$ dari pola bilangan persegi atau kudrat yang pernah diperoleh saat pembelajaran daring, sampai mengaitkannya dengan luas bangun datar persegi yang diketahui ketika masih sekolah dasar. Sementara argumentasi yang disampaikan untuk mendukung penyalinan algoritme, berdasar pada sifat intrinsik matematika yaitu mengidentifikasi jenis pola bilangan berdasarkan beda antar pola.

Argumentasi yang disampikan untuk mendukung penyalinan jawaban, telah memunculkan unsur plausibility pada penalaran imitatif namun tidak pada penalaran kreatif. Lain hal dengan argumentasi yang disampaikan untuk mendukung penyalinan algoritme, argumentasi tersebut telah berhasil memunculkan unsur plausibility pada penalaran imitative dan kreatif. Meskipun sebenarnya dalam penalaran imitatif tipe AR tidak harus selalu memerhatikan sifat intrinsik dari unsur tugas (Lithner, 2017).

Pada tugas ke-3, terdapat 9 penyelesaian yang berhasil dikumpulkan. Siswa tidak kesulitan menyebutkan informasi dan pertanyaan tugas secara lengkap, serta menyampaikan strategi yang dibangun secara runtut untuk menyelesaikan tugas ke-3. Sebagian besar strategi dimulai dengan memahami tugas melalui analisis terhadap berbagai informasi 
yang disajikan baik berupa tulisan, gambar, maupun tabel. Dilanjutkan dengan pemilihan lompatan yang tidak dapat dilakukan secara acak, siswa harus mulai memikirkan jenis barisan bilangan yang dibentuk sehingga tidak kesulitan menentukan rumus yang akan digunakan untuk mencari lompatan ke20. Hal ini tidak dapat dilakukan jika siswa hanya mengandalkan penalaran imitatif yaitu menyalin apa yang telah disampaikan, dibutuhkan pemahaman dan penguasaan konsep sehingga siswa mampu menyeleksi jenis barisan bilangan yang termuat dalam lintasan lompat pola. Sejalan dengan Lithner (2017) yang menyatakan bahwa pembelajaran yang melibatkan CMR (Creative Mathematical Reasoning) lebih efisien dalam membangun pemahaman matematika.

Siswa cenderung hanya memunculkan satu unsur kebaruan ketika menghadapi open task terkait penentuan suku ke- $n$ dari cerita yang disajikan. Hal tersebut dikarenakan tugas sejenis ini tidak sepenuhnya baru bagi siswa. Penentuan suku ke- $n$ dari suatu barisan bilangan merupakan jenis tugas yang sering dihadapi, terlebih hampir semua jenis pola bilangan yang termuat dalam tabel telah disampaikan oleh guru matematika. Meskipun penyajian cerita yang melibatkan tabel dan bilangan acak menjadi hal baru bagi siswa.

Satu unsur kebaruan yang dimunculkan terletak pada penentuan lompatan yang membentuk barisan bilangan. Hal tersebut merupakan suatu kebaruan karena siswa menyusun strategi sesuai kreativitasnya sendiri tanpa menyalin cara atau jawaban dari tugas sebelumnya, mulai dari penentuan lompatan awal sampai lompatan terakhir. Sementara penulisan algoritma merupakan penyalinan dari apa yang sudah diajarkan guru di kelas. Adapun penyelesaian yang mampu memunculkan dua unsur kebaruan, menggunakan cara yang sudah banyak di lupakan seperti pada Gambar 4 dan Gambar 5 untuk mendapatkan bilangan pada lompatan ke-20.

Hanya sebagian kecil siswa yang menggunakan cara tabel dan penjumlahan manual dikarenakan cara tersebut membutuhkan waktu lama, banyak siswa meninggalkan kedua cara tersebut dan memilih rumus aritmatika. Terbukti dengan banyaknya penggunaan rumus aritmatika untuk menyelesaikan tugas ke-3 dan ke-4. Penggunaan rangkaian solusi yang baru bagi siswa atau penggunaan kembali solusi lama yang sudah dilupakan banyak orang dapat dikatakan sebagai novelty (Sidenvall et al., 2015).

Secara umum, tidak terlihat adanya kesulitan pada pemenuhan unsur plausibility. Hanya terdapat satu penyelesaian yang gagal menjelaskan apakah hasil yang didapat telah menjawab pertanyaan tugas. Siswa menyampaikan bahwa dia yakin jika hasil penyelesaiannya telah sesuai dan hanya mengandalkan perasaan subjektif. Sebagaimana pernyataannya berikut, "Sudah sesuai, karena seperti sudah yakin". Padahal, suatu argumentasi yang disampaikan harus berlandaskan sifat intrinsik matematika dari setiap komponen yang terlibat (Lithner, 2015). Dalam hal ini, komponen yang dimaksud merupakan pertanyaan tugas dan hasil penyelesaian.

Sementara

penyampaian keterkaitan dari informasi yang diketahui dengan informasi lain atau pun pertanyaan tugas dapat dilakukan dengan mudah. Kemampuan mengaitkan setiap komponen tugas dapat dilakukan apabila siswa memiliki keterampilan matematika dalam ranah konkret (seperti mengurai, merangkai, memodifikasi) dan dalam ranah abstrak 
DOI: https://doi.org/10.24127/ajpm.v10i4.3887

(seperti membaca dan menghitung) dengan baik (Kemdikbud, 2018). Siswa juga dapat memberikan argumentasi logis mengenai pemilihan dan penerapan strategi yang dikembangkan. Sebagian besar pemilihan strategi berdasar pada hasil identifikasi jenis pola bilangan yang dibentuk, sementara penjelasan penerapan berkaitan dengan alasan substitusi bilangan tertentu pada rumus yang dipilih.

Terdapat satu penyelesaian pada tugas ke-3 dan ke-4 yang tidak berhasil memenuhi unsur flexibility. Meskipun telah dirancang sesuai karakteristik open task yaitu memungkinkan siswa mengaplikasikan sejumlah strategi penyelesaian (Kurniasih, 2014). Namun, siswa hanya menyajikan satu cara penyelesaian dan merasa tidak bisa menyajikan cara lain. Sebab, penalaran yang digunakan dalam menyelesaikan suatu tugas tidak hanya bergantung pada karakteristik tugas tetapi juga berhubungan dengan kegiatan siswa dalam konteks sosial (Boesen et al., 2010). Hal ini juga berlaku pada pemenuhan unsur flexibility yang bergantung pada kemampuan dan pengalaman belajar setiap siswa.

Pada tugas ke-4, terdapat 9 penyelesaian yang dapat dikumpulkan. Siswa tidak kesulitan menyebutkan unsur yang diketahui dan ditanyakan, namun kesulitan dalam menentukan strategi berdasarkan sifat intrinsik matematika yang relevan dengan informasi pada tugas dan kesulitan menerapkan strategi yang dipilih. Penyelesaian yang membangun strategi dengan memuat perhitungan persegi korek api seperti yang tersaji pada Gambar 7, tidak sesuai dengan informasi tugas yang menyatakan bahwa pola yang terbentuk akan mengalami pertambahan banyaknya korek api dari kartu sebelumnya. Selain itu, kurangnya pemahaman siswa terhadap konsep rumus suku ke- $n$ yang justru menganggap rumus dasar aritmatika yaitu $U_{n}=a+(n-1) b$ sebagai jawaban tugas, menjadi salah satu penyebab ketidakmampuan siswa menerapkan strategi yang telah dipilih.

Konsep merupakan ide abstrak yang mengklasifikasikan suatu objek apakah termasuk contoh atau bukan contoh dari ide abstrak tersebut (Andar \& Ikman, 2016). Kurangya kemampuan siswa memahami konsep mengakibatkan penerapan strategi yang dilakukan tidak berdasar pada sifat intrinsik matematika. Padahal, suatu penyelesaian memuat mathematical foundation apabila argumen yang disampaikan berdasar pada sifat intrinsik matematika yang melibatkan komponen-komponen, seperti: objek, transformasi, dan konsep.

Siswa cenderung hanya memunculkan satu unsur kebaruan ketika menghadapi open task terkait menentukan rumus suku ke- $n$ dari suatu konfigurasi objek. Walaupun demikian, persentase pemenuhan unsur novelty pada tipe GCR tidak terpaut jauh dengan tipe LCR yaitu 6\%. Artinya, siswa memiliki kesempatan lebih besar memunculkan unsur kebaruan pada seluruh penyelesaian ketika menghadapi open task seperti tugas ke-4 dibanding tugas ke-3. Hal ini bisa terjadi karena konfigurasi objek yang disajikan pada tugas ke-4 dapat dipahami dengan lebih banyak cara dibanding lintasan yang tersaji pada tugas ke-3, sehingga siswa terdorong untuk menjadi semakin kreatif. Hasil kreativitas siswa dapat terlihat pada pemilihan empat kartu yang membentuk barisan bilangan. Hal tersebut merupakan hal baru bagi siswa, sebab tugas ke-4 tidak pernah ditemui sebelumnya. Sejalan dengan Sidenvall et al., (2015) yang menyatakan bahwa suatu rangkaian solusi yang baru bagi siswa dapat disebut sebagai novelty. 
DOI: https://doi.org/10.24127/ajpm.v10i4.3887

Penyelesaian yang hanya memunculkan satu unsur kebaruan, menyalin algoritme yang pernah disampaikan oleh guru matematika seperti rumus aritmatika bertingkat yang tersaji pada Gambar 7. Siswa cenderung menggunakan algoritme yang telah diketahui, dibanding mengeksplorasi algoritme lain yang sekiranya sesuai. Apabila siswa meningkatkan kreativitasnya dan memperluas penguasaan materi dengan memperbanyak sumber belajar, maka siswa memiliki kemungkinan lebih besar untuk dapat memunculkan unsur novelty pada seluruh rangkaian penyelesaian. Suatu penyelesaian yang menghasilkan jawaban atau pun cara berbeda dengan siswa lain atau tidak biasa untuk tingkat pengetahuannya namun tetap bernilai benar disebut memunculkan novelty (Alifiyah \& Kurniasari, 2019).

Berbeda yang dimaksud adalah tidak digunakan secara umum oleh siswa dalam kelasnya dan bukan merupakan algoritma yang diajarkan oleh guru matematika seperti yang disajikan pada Gambar 8. Siswa menggunakan rumus aritmatika bertingkat yang berbeda dari apa yang disampaikan oleh guru matematika, sehingga tidak ada penyelesaian lain dalam kelas tersebut yang menggunakan cara yang sama. Rumus tersebut diketahuinya ketika belajar mandiri dari internet maupun bimbingan belajar online.

Penyelesaian berbeda lain menggunakan cara menguraikan setiap pola hingga membentuk bilangan yang sama seperti pada Gambar 9. Bahkan, menjadi percobaan pertama siswa setelah dulu pernah mempelajarinya dari internet. Sebagaimana pernyataannya berikut: "Sebelumnya saya belum pernah menggunakan rumus ini, masih coba-coba dan kebetulan bisa". Jadi, selain berbeda dengan siswa lain cara ini juga disebut sebagai novelty karena menggunakan rangkaian solusi yang baru bagi siswa (Sidenvall et al., 2015).

Tabel 5. Capaian Indikator Penalaran Imitatif Masing-Masing Nomor

\begin{tabular}{cccccccc}
\hline No. & & IR & & & \multicolumn{3}{c}{ AR } \\
\cline { 2 - 4 } \cline { 7 - 8 } Tugas & $\mathbf{M}$ & $\mathbf{I}$ & $\mathbf{P}$ & & $\mathbf{M}$ & $\mathbf{I}$ & $\mathbf{P}$ \\
\hline 1 & $10 / 10$ & $1 / 5$ & $1 / 5$ & & $14 / 15$ & $3 / 5$ & $2 / 5$ \\
& $(100 \%)$ & $(20 \%)$ & $(20 \%)$ & & $(99 \%)$ & $(60 \%)$ & $(40 \%)$ \\
\hline 2 & $10 / 10$ & $4 / 5$ & $4 / 5$ & & $11 / 15$ & $1 / 5$ & $1 / 5$ \\
& $(100 \%)$ & $(80 \%)$ & $(80 \%)$ & & $(73 \%)$ & $(20 \%)$ & $(20 \%)$ \\
\hline 3 & $18 / 18$ & $0 / 9$ & $0 / 9$ & & $24 / 27$ & $6 / 9$ & $6 / 9$ \\
& $(100 \%)$ & $(0 \%)$ & $(0 \%)$ & & $(88,9 \%)$ & $(66,7 \%)$ & $(66,7 \%)$ \\
\hline 4 & $18 / 18$ & $0 / 9$ & $0 / 9$ & & $23 / 27$ & $5 / 9$ & $5 / 9$ \\
& $(100 \%)$ & $(0 \%)$ & $(0 \%)$ & & $(85,2 \%)$ & $(55,6 \%)$ & $(55,6 \%)$ \\
\hline
\end{tabular}

Keterangan:

M : mathematical foundation

I : imitation

P : plausibility

Siswa tidak kesulitan ketika harus menjelaskan hubungan antara informasi yang disajikan ataupun ketika menyampaikan predictive argumentation. Predictive argumentation merupa- kan argumentasi yang mendukung pemilihan strategi dengan menjelaskan 'kenapa strategi tersebut dapat menyelesaikan tugas?' (Bergqvist \& Lithner, 2012). Seluruh siswa beralasan 
DOI: https://doi.org/10.24127/ajpm.v10i4.3887

bahwa strategi yang dibangun disesuaikan dengan jenis barisan bilangan yang dibentuk oleh empat kartu terpilih, sehingga setiap argumentasi didasarkan pada sifat intrinsik matematika. Sedangkan, tidak semua siswa dapat memberikan verificative argumentation. Verificative argumenta-tion merupakan argumentasi mengenai cara suatu strategi sehingga dapat menghasilkan suatu jawaban benar (Bergqvist \& Lithner, 2012).

Berdasarkan deskripsi pemenuhan indikator unsur penalaran imitatif dan kreatif di atas, proporsi dan persentase capaian indikator penalaran imitatif masing-masing nomor disajikan pada Tabel 5. Sementara, proporsi dan persentanse capaian indikator penalaran kreatif disajikan pada Tabel 6.

Tabel 6. Capaian Indikator Penalaran Kreatif Masing-Masing Nomor

\begin{tabular}{|c|c|c|c|c|c|c|c|c|}
\hline \multirow{2}{*}{$\begin{array}{c}\text { No. } \\
\text { Tugas }\end{array}$} & \multicolumn{4}{|c|}{ LCR } & \multicolumn{4}{|c|}{ GCR } \\
\hline & $\mathbf{M}$ & $\mathbf{N}$ & $\mathbf{F}$ & $\mathbf{P}$ & M & $\mathbf{N}$ & $\mathbf{F}$ & $\mathbf{P}$ \\
\hline 1 & $\begin{array}{l}10 / 20 \\
(50 \%)\end{array}$ & $\begin{array}{l}0 / 10 \\
(0 \%)\end{array}$ & $\begin{array}{l}0 / 10 \\
(0 \%)\end{array}$ & $\begin{array}{c}4 / 25 \\
(16 \%)\end{array}$ & $\begin{array}{c}10 / 20 \\
(50 \%)\end{array}$ & $\begin{array}{l}0 / 10 \\
(0 \%)\end{array}$ & $\begin{array}{l}0 / 10 \\
(0 \%)\end{array}$ & $\begin{array}{c}4 / 25 \\
(16 \%)\end{array}$ \\
\hline 2 & $\begin{array}{l}10 / 20 \\
(50 \%)\end{array}$ & $\begin{array}{l}0 / 10 \\
(0 \%)\end{array}$ & $\begin{array}{l}0 / 10 \\
(0 \%)\end{array}$ & $\begin{array}{l}2 / 25 \\
(8 \%)\end{array}$ & $\begin{array}{c}10 / 20 \\
(50 \%)\end{array}$ & $\begin{array}{l}0 / 10 \\
(0 \%)\end{array}$ & $\begin{array}{l}0 / 10 \\
(0 \%)\end{array}$ & $\begin{array}{l}2 / 25 \\
(8 \%)\end{array}$ \\
\hline 3 & $\begin{array}{c}36 / 36 \\
(100 \%)\end{array}$ & $\begin{array}{l}15 / 18 \\
(83 \%)\end{array}$ & $\begin{array}{c}8 / 9 \\
(89 \%)\end{array}$ & $\begin{array}{l}43 / 45 \\
(96 \%)\end{array}$ & $\begin{array}{c}36 / 36 \\
(100 \%)\end{array}$ & $\begin{array}{l}12 / 18 \\
(67 \%)\end{array}$ & $\begin{array}{c}8 / 9 \\
(89 \%)\end{array}$ & $\begin{array}{l}44 / 45 \\
(96 \%)\end{array}$ \\
\hline 4 & $\begin{array}{l}32 / 36 \\
(89 \%)\end{array}$ & $\begin{array}{c}14 / 18 \\
(78 \%)\end{array}$ & $\begin{array}{c}8 / 9 \\
(89 \%)\end{array}$ & $\begin{array}{l}42 / 45 \\
(93 \%)\end{array}$ & $\begin{array}{l}32 / 36 \\
(89 \%)\end{array}$ & $\begin{array}{l}13 / 18 \\
(72 \%)\end{array}$ & $\begin{array}{c}8 / 9 \\
(89 \%)\end{array}$ & $\begin{array}{l}42 / 45 \\
(93 \%)\end{array}$ \\
\hline
\end{tabular}

Keterangan:

M : mathematical foundation $\quad$ F : flexibility

$\mathrm{N}$ : novelty $\quad \mathrm{P} \quad$ : plausibility

Tabel 7. Tipe Penalaran Matematis yang Muncul pada Masing-Masing Nomor

\begin{tabular}{cccccc}
\hline $\begin{array}{c}\text { Tugas } \\
\text { ke- }\end{array}$ & $\begin{array}{c}\text { Memunculkan } \\
\text { MR }\end{array}$ & $\begin{array}{c}\text { Memunculkan } \\
\text { AR }\end{array}$ & $\begin{array}{c}\text { Memunculkan } \\
\text { LCR }\end{array}$ & $\begin{array}{c}\text { Memunculkan } \\
\text { GCR }\end{array}$ & $\begin{array}{c}\text { Tidak } \\
\text { memunculkan } \\
\text { Penalaran }\end{array}$ \\
\hline 1 & $1 / 5(20 \%)$ & $2 / 5(40 \%)$ & $0 / 5(0 \%)$ & $0 / 5(0 \%)$ & $2 / 5(40 \%)$ \\
2 & $4 / 5(80 \%)$ & $1 / 5(20 \%)$ & $0 / 5(0 \%)$ & $0 / 5(0 \%)$ & $0 / 5(0 \%)$ \\
3 & $0 / 5(0 \%)$ & $0 / 5(0 \%)$ & $5 / 9(56 \%)$ & $3 / 9(33 \%)$ & $1 / 9(11 \%)$ \\
4 & $0 / 5(0 \%)$ & $0 / 5(0 \%)$ & $3 / 9(33,3 \%)$ & $3 / 9(33,3 \%)$ & $3 / 9(33,3 \%)$ \\
\hline
\end{tabular}

Proporsi pada Tabel 5 dan Tabel 6, merupakan hasil perbandingan antara jumlah indikator dengan jumlah capaian indikator maksimum. Jumlah Capaian indikator maksimum diperoleh dari hasil kali antara banyaknya indikator pada setiap unsur dengan banyaknya hasil penyelesaian pada masing-masing nomor. Berdasarkan Tabel 4, diketahui bahwa sangat sulit memunculkan unsur imitasi jawaban yang telah diketahui dari tugas sebelumnya pada tugas ke-3 dan ke-4. Sebaliknya, melalui Tabel 5 diketahui bahwa sangat sulit memunculkan unsur novelty pada tugas ke-1 dan ke-2. Berdasarkan Tabel 4 dan Tabel 5, dapat diketahui tipe penalaran matematis yang muncul pada masingmasing nomor yang disajikan pada Tabel 7.

Tabel 7 menunjukkan bahwa tugas ke-1 memungkinkan siswa untuk memunculkan penalaran imitatif tipe AR, bahkan memiliki persentase yang sama besar dengan kemungkinan untuk tidak memunculkan penalaran 
matematika. Sementara tugas ke-2, memiliki kecenderungan yang cukup tinggi dalam memunculkan penalaran imitatif tipe MR. Tugas ke-3 sama sekali tidak memungkinkan untuk memunculkan penalaran imitatif, namun cukup baik dalam memunculkan penalaran kreatif tipe LCR. Sama hal nya dengan tugas ke-4 yang menampilkan persentase $0 \%$ dalam memunculkan penalaran imitatif. Bentuk tugas ke-4 memungkinkan siswa untuk memunculkan penalaran kreatif tipe LCR maupun GCR, bahkan memungkinkan siswa untuk sama sekali tidak memunculkan penalaran matematik dengan besar kemungkinan yang sama.

\section{KESIMPULAN DAN SARAN}

Closed task yang menanyakan rumus suku ke- $n$ yang telah diketahui siswa akan memunculkan tipe MR, sebaliknya closed task yang berkaitan dengan penerapan rumus yang telah diketahui siswa untuk mencari suku selanjutnya dari suatu barisan bilangan akan memunculkan tipe AR. Open task yang menanyakan pola ke- $n$ dari konfigurasi objek dan banyak melibatkan hal baru bagi siswa akan cenderung memunculkan tipe GCR, sebaliknya open task yang menanyakan suku selanjutya dari barisan bilangan dan tidak sepenuhnya baru/banyak melibatkan hal-hal yang telah diketahui siswa cenderung memunculkan tipe LCR

\section{DAFTAR PUSTAKA}

Alifiyah, Y. R., \& Kurniasari, I. (2019). Identifikasi Tingkat Berpikir Kritis Siswa dalam Memecahkan Masalah Open Ended ditinjau dari Gaya Berpikir Stenberg. MATHEdunesa, 8(2), 216-222.

Andar, A., \& Ikman, I. (2016). Deskripsi Kesalahan Siswa Dalam
Menyelesaikan Soal-Soal Ujian Semester Matematika Siswa Kelas Viii Smp Negeri 10 Kendari. Jurnal Penelitian Pendidikan Matematika, 4(2), 15-28.

Ayal, C. S., Kesuma, Y. S., Sabandar, J., \& Dahlan, J. A. (2016). The Enhancement of Mathematical Reasoning Ability of Junior High School Students by Applying Mind Mapping Strategy. Journal of Education and Practice, 7(25), 5058.

Bergqvist, E. (2007). Types of reasoning required in university exams in mathematics. Journal of Mathematical Behavior, 26(4), 348-370.

https://doi.org/10.1016/j.jmathb.20 07.11 .001

Bergqvist, E. (2012). University Mathematics Teachers' Views on the Required Reasoning in Calculus Exams. The Mathematics Enthusiast, 9(3), 371-408.

Bergqvist, T., \& Lithner, J. (2012). Mathematical reasoning in teachers' presentations. Journal of Mathematical Behavior, 31(2), 252-269.

https://doi.org/10.1016/j.jmathb.20 11.12.002

Berisha, V., \& Bytyqi, R. (2020). Types of Mathematical Tasks Used in Secondary Classroom Instruction. International Journal of Evaluation and Research in Education, 9(3), 751-758. https://doi.org/10.11591/ijere.v9i3. 20617

Boesen, J., Lithner, J., \& Palm, T. (2010). The relation between types of assessment tasks and the mathematical reasoning students use. Educational Studies in Mathematics, 75(1), 89-105. https://doi.org/10.1007/s10649010-9242-9 
DOI: https://doi.org/10.24127/ajpm.v10i4.3887

Dwirahayu, G., Mas'ud, A., Satriawati, G., Atiqoh, K. S. N., \& Dewi, S. (2021). Improving students mathematical creative reasoning on polyhedron through concept-based inquiry model Improving students, mathematical creative reasoning on polyhedron through concept-based inquiry model. Journal of Physics: Conference Series, 1-10. https://doi.org/10.1088/17426596/1836/1/012073

Johnson, H. L., Coles, A., \& Clarke, D. J. (2017). Mathematical tasks and the student: navigating "tensions of intentions" between designers, teachers, and students. ZDM-The International Journal on Mathematics Education, 49(6), 813-822.

Jones, K. \& Pepin, B. (2016). Research on mathematics teachers as partners in task design. Journal of Mathematics Teacher Education, 19, $105-121$.

Kemdikbud. (2018). Peraturan Menteri Pendidikan dan Kebudayaan Republik Indonesia Nomor 35. Jakarta: Kementrian Pendidikan dan Kebudayaan.

Koichu, B., Zaslavsky, O., \& Dolev, L. (2016). Effects of variations in task design on mathematics teachers' learning experiences: A case of sorting task. Journal of Mathematics Teacher Education, 19, 349-370.

Kurniasih, A. W. (2014). Budaya Mengembangkan Soal Cerita Kontekstual Open-Ended Mahasiswa Calon Guru Matematika untuk Meningkatkan Berpikir Kritis. 5, 9-17.Kusaeri, K. (2020). Reorientasi penilai-an pembelajaran Matemati-ka: Dulu, kini, dan mendatang. Naskah Pidato Pengukuhan Guru Besar Bidang Evaluasi Pembelajaran
Matematika. Surabaya: UIN Sunan Ampel Surabaya.

Lithner, J. (2015). Selected Regular Lectures from the 12th International Congress on Mathematical Education. Selected Regular Lectures from the 12th International Congress on Mathematical Education, 487-506. https://doi.org/10.1007/978-3-31917187-6

Lithner, J. (2017). Principles for designing mathematical tasks that enhance imitative and creative reasoning. ZDM - Mathematics Education, 49(6), 937-949. https://doi.org/10.1007/s11858017-0867-3

Rosita, N.T., Sukestiyarno, Y. L., Kartono, \& Mulyono. (2020). The Analysis of Students Mathematical Reasoning in Completing the Word Problem in SMPN 7 Sumedang. 443, 115-119. https://doi.org/10.2991/assehr.k.20 0620.023

Olsson, J. (2019). Relations Between Task Design and Students' Utilization of GeoGebra. Digital Experiences in Mathematics Education, 5(3), 223-251. https://doi.org/10.1007/s40751019-00051-6

Palm, T., Boesen, J., \& Lithner, J. (2011). Mathematical reasoning requirements in Swedish upper secondary level assessments. Mathematical Thinking and Learning, 13(3), 221-246. https://doi.org/10.1080/10986065.2 011.564994

Permatasari, N., Darhim, D., \& Jupri, A. (2020). Students' imitative and creative reasoning ability in solving geometry problems. Journal of Physics: Conference Series, $1469(1)$. https://doi.org/10.1088/1742- 
DOI: https://doi.org/10.24127/ajpm.v10i4.3887

6596/1469/1/012166

Prahmana, R. C. I. (2016). Local Instruction Theory Penelitian Pendidikan Matematika untuk Menumbuhkan Keterampilan Mahasiswa Calon Guru dalam Melakukan Penelitian dan Menulis Karya Ilmiah (Issue August) [Universitas Pendidikan Indonesia].

https://doi.org/10.13140/RG.2.2.27 173.70883

Rizta, A., Zulkardi, Z., \& Hartono, Y. (2013). Pengembangan Soal Penalaran Model Timss Matematika SMP. Jurnal Penelitian Dan Evaluasi Pendidikan, 17(2), 230-240. https://doi.org/10.21831/pep.v17i2. 1697

Romli, S. (2019). Pengembangan Lembar Kerja Siswa ( LKS ) Berbasis Open Ended ( Tesis ) (Issue January) [Universitas Lampung]. https://doi.org/10.13140/RG.2.2.21 100.51844

Sidenvall, J., Lithner, J., \& Jäder, J. (2015). Students' reasoning in mathematics textbook task-solving.

\author{
International Journal of \\ Mathematical Education in \\ Science and Technology, 46(4), \\ 533-552. \\ https://doi.org/10.1080/0020739X. \\ 2014.992986
}

Sukirwan, Darhim, D., \& Herman, T. (2018). Analysis of students' mathematical reasoning. Journal of Physics: Conference Series, 948(1).

https://doi.org/10.1088/17426596/948/1/012036

Sutini, S., Aaidati, I. F., \& Kusaeri, K. (2020). Identifying The Structure of Students' Argumentation in Covariational Reasoning of Constructing Graphs. Beta: Jurnal Tadris Matematika, 13(1), 61-80. https://doi.org/10.20414/betajtm.v1 3i1.374

Swan, M. (2011). Designing tasks that challenge values, beliefs, and practices: A model for the professionaldevelopment of practicing teachers. In O. Zaslavsky \& P. Sullivan (Eds.), Constructing knowledge forteaching secondary mathematics. New York: Springer. 